\title{
Safety and efficacy of resistance training in germ cell cancer patients undergoing chemotherapy: a randomized controlled trial
}

\author{
J F Christensen ${ }^{\star}, 1,2$, L W Jones ${ }^{3}$, A Tolver ${ }^{4}$, L W Jørgensen ${ }^{1}$, J L Andersen ${ }^{5,6}$, L Adamsen ${ }^{1}$, P Højman ${ }^{7}$, \\ R H Nielsen ${ }^{5,6}, M_{\text {Rørth }}^{1,2}$ and G Daugaard ${ }^{2}$ \\ ${ }^{1}$ University Hospitals Centre for Health Research, Rigshospitalet, DK 2100 Copenhagen, Denmark; ${ }^{2}$ Department of Oncology, \\ Rigshospitalet, DK 2100 Copenhagen, Denmark; ${ }^{3}$ Memorial Sloan-Kettering Cancer Center, Department of Cardiology, New York, \\ NY 10065, USA; ${ }^{4}$ Department of Mathematical Sciences, University of Copenhagen, DK 2100 Copenhagen, Denmark; Institute of \\ Sports Medicine Copenhagen, Department of Orthopaedic Surgery, Bispebjerg Hospital, DK 2400 Copenhagen, Denmark; \\ ${ }^{6}$ Centre for Healthy Ageing, Faculty of Health Sciences, University of Copenhagen, DK 2100 Copenhagen, Denmark and \\ ${ }^{7}$ Research Centre of Inflammation and Metabolism, Rigshospitalet, DK 2100 Copenhagen, Denmark
}

Background: Bleomycin-etoposid-cisplatin (BEP) chemotherapy is curative in most patients with disseminated germ cell cancer (GCC) but also associated with toxic actions and dysfunction in non-targeted tissues. We investigated changes in muscle function during BEP and the safety and efficacy of resistance training to modulate these changes.

Methods: Thirty GCC patients were randomly assigned to resistance training (resistance training group (INT), $n=15$ ) or usual care $(C O N, n=15)$ during 9 weeks of BEP therapy. Resistance training consisted of thrice weekly sessions of four exercises, 3-4 sets/ exercise of 10-15 repetitions at 12-15 repetition maximum load. The primary endpoint was muscle fibre size, assessed in muscle biopsies from musculus vastus lateralis. Secondary endpoints were fibre phenotype composition, body composition, strength, blood biochemistry and patient-reported endpoints. Healthy age-matched subjects (REF, $n=19$ ) performed the same RT-programme for comparison purposes.

Results: Muscle fibre size decreased by $-322 \mu \mathrm{m}^{2}(95 \%$ confidence interval $(\mathrm{Cl}):-899$ to $255 ; P=0.473)$ in the CON-group and increased by $+206 \mu \mathrm{m}^{2}(95 \% \mathrm{Cl}:-384$ to $796 ; P=0.257)$ in the INT-group (adjusted mean difference (AMD), $+625 \mu \mathrm{m}^{2}, 95 \% \mathrm{Cl}$ : -253 to $1503, P=0.149$ ). Mean differences in type II fibre size (AMD, $+823 \mu \mathrm{m}^{2}, P=0.09$ ) and lean mass (AMD, $+1.49 \mathrm{~kg}$, $P=0.07$ ) in favour of the INT-group approached significance. The REF-group improved all muscular endpoints and had significantly superior changes compared with the INT-group $(P<0.05)$.

Conclusions: BEP was associated with significant reduction in lean mass and strength and trends toward unfavourable changes in muscle fibre size and phenotype composition. Resistance training was safe and attenuated dysfunction in selected endpoints, but BEP blunted several positive adaptations observed in healthy controls. Thus, our study does not support the general application of resistance training in this setting but larger-scaled trials are required to confirm this finding.

Testicular germ cell cancer (GCC) is highly curable with 5-year survival surpassing 90\% (Beyer et al, 2013). This is due, in large part, to the efficacy of combination chemotherapy with bleomycinetoposide-cisplatin (BEP) in patients with disseminated disease
(Einhorn, 1990). However, it is well established that BEP is associated with acute toxicities and increased incidence of longterm morbidities including metabolic syndrome (Haugnes et al, 2010) and cardiovascular (CV) diseases (Fossa et al, 2007).

*Correspondence: JF Christensen; E-mail: jfc@rh.regionh.dk

Received 18 February 2014; revised 14 April 2014; accepted 28 April 2014; published online 27 May 2014

(c) 2014 Cancer Research UK. All rights reserved 0007-0920/14 
The underlying mechanisms are not fully elucidated and strategies to abrogate these events have not been investigated.

Skeletal muscle is the largest organ in the human body, and the integrated properties of muscle mass and intramuscular qualities (i.e. Fibre phenotype composition, capillary density, oxidative capacity and so on) are essential for regulating whole-body homoeostasis and hence protection against metabolic disorders (Sayer et al, 2005; Atlantis et al, 2009). Moreover, muscle dysfunction, as characterised by low muscle mass and/or strength, comprises an independent predictor of mortality in the general population (Ruiz et al, 2008) and various malignancies (Christensen et al, 2014). Early-localised muscular fatigue and severe deconditioning are common observations in clinical practice involving GCC patients undergoing BEP therapy. Thus, BEP is likely associated with considerable impairments in muscular properties, that is, muscle fibre atrophy, loss of lean mass and impaired strength, which may predispose to adverse metabolic and/or CV late effects. However, to our knowledge, no studies to date have investigated the level and mechanisms underlying this phenomenon.

In healthy individuals, resistance training (RT) promotes widespread physiologic adaptations in all aspects of muscle function. RT, as characterised by muscle contractions against high external force, induces homoeostatic perturbations including mechanical stress, mechano-sensation and calcium flux. These stimuli activate various downstream signalling cascades ultimately promoting protein synthesis, inhibiting protein degradation and modulating muscle gene expression (Egan and Zierath, 2013). In concert, these adaptations result in muscle fibre hypertrophy and improved biochemical profile which translate into clinically relevant improvements in body composition, strength and control of metabolic homoeostasis (Egan and Zierath, 2013). Because of the capacity to improve these physiological properties, RT is considered an important concomitant strategy to the medical treatment in pathologies associated with muscle dysfunction (Puhan et al, 2005; Eves and Plotnikoff, 2006). It remains unknown, however, whether such adaptations are achievable in GCC patients undergoing BEP-therapy and/or whether such adaptations are on a similar level to those observed in healthy individuals.

Against this background, we conducted the Progressive Resistance Training and Cancer Testis (PROTRACT) study to explore two major questions: (I) the effects of BEP therapy on muscle function and (II) the efficacy of RT to prevent and/or mitigate anticipated therapy-induced muscle dysfunction in GCC patients. A secondary explorative objective was to investigate the comparative efficacy of RT in GCC patients compared with healthy controls.

\section{MATERIALS AND METHODS}

The PROTRACT study was a prospective randomised controlled trial in patients with disseminated GCC conducted at Rigshospitalet, Copenhagen, Denmark. The overall design and methodology have been previously described (Christensen et al, 2011). In brief, patients with disseminated GCC belonging to the 'good prognostic group' according to established international guidelines were eligible (International Germ Cell Cancer Collaborative Group, 1997). Major exclusion criteria were (i) age $<18$ and $>50$ years (ii) presence of clinically important CV disease (cardiomyopathy, coronary heart disease and so on), (iii) presence of chronic disease (diabetes mellitus, chronic obstructive pulmonary disease and so on) and (iv) inability to read and understand Danish. For comparison, a reference group of age- and BMI-matched healthy male individuals was recruited and screened for the same major exclusion criteria.
All subjects signed a written consent, prior to the initiation of any study-related procedures.

Therapy. BEP therapy consisted of cisplatin $20 \mathrm{mg} \mathrm{m}^{-2}$ and etoposide $100 \mathrm{mg} \mathrm{m}^{-2}$ daily for 5 days and bleomycin $15000 \mathrm{IE} \mathrm{m}^{-2}$ weekly administered in a 3-week schedule. All patients received standard antiemetic treatment with prednisolone (50 mg daily), 5HT3-antagonists and metopimazine during the initial 5 days of each cycle.

Group allocation and blinding. Prior to the initiation of the study, a clinician not involved in any other study procedures used a simple coin-based procedure to generate a random list of group assignments in sequentially numbered, opaque, sealed envelopes. Thus, following all baseline assessments GCC patients were randomly allocated with a ratio of $1: 1$ to either RT intervention (INT) or usual care (CON). The healthy reference group (REF) was allocated to resistance training. Study personnel conducting the assessment and analysis of muscle biopsies (primary endpoint) were blinded to group assignment. Personnel responsible for assessments of secondary endpoints were not blinded for group allocation.

Resistance training. RT consisted of 3 weekly supervised (hospital-based) sessions for 9 weeks, comprising four upper and lower extremity exercises: leg press, knee extension, chest press and lateral pulldown using stationary equipment (Technogym, Gambettola, Italy). For the initial five sessions, participants performed three sets of 15 repetitions at 15 repetition maximum (RM) load. From session six and onward, participants performed four sets of 10 repetitions at 10-12 RM load. Individual supervision by an instructor ensured training load was continuously increased when a participant could perform more than 12 repetitions on a given load. The number of RT sessions and the mean relative load (\% of pre-training 1RM) for each exercise was calculated through all 9 weeks, and for Weeks 1-3, Weeks 4-6 and Weeks 7-9, respectively.

Usual care. Participants allocated to the CON group received standard care as provided by the Department of Oncology. Patients were allowed to exercise on their own initiative, or participate in any standard care hospital- or community-based exercise programs.

Assessment timing. All baseline assessments were conducted before the first cycle of BEP and all week 9 assessments were conducted within one week of the completion of the 3rd BEP cycle.

Primary end point. Primary end point was change from baseline to end-of-therapy in mean muscle fibre size evaluated as the cross sectional area $\left(\mu \mathrm{m}^{2}\right)$ in muscle biopsies taken from musculus vastus lateralis using the Bergstrom technique (Bergström, 1962). Mean fibre size was also reported for type I and type II fibres, respectively. The muscle tissues were immediately mounted with Tissue-Tek (Sakura Finetek, Torrance, CA, USA) and frozen in isopentane, cooled with liquid nitrogen and stored at $-80^{\circ} \mathrm{C}$. Serial sections $(10 \mu \mathrm{m})$ of the muscle biopsy samples were cut in a cryostat $\left(-20^{\circ} \mathrm{C}\right)$ and routine ATPase histochemistry analysis was performed after preincubation at $\mathrm{pH} 4.37,4.60$ and 10.30, as previously described (Andersen and Aagaard, 2000).

Secondary end points. Muscle fibre phenotype distribution was assessed in biopsies and reported as the proportion (percentage) of type I fibres, while the proportion of type II fibres was subcategorized by type IIa and type IIx (Andersen and Aagaard, 2000).

Quadriceps muscle strength was assessed by maximum isometric torque (Metitur Oy, FI-40250 Jyväskylä, Finland). Participants were seated with a fixed knee angle of $60^{\circ}$ and performed three maximum voluntary contractions for each leg and the maximum score was recorded. The INT and REF groups also performed 1-RM tests for all exercises. 
Body composition was assessed by dual energy X-ray absorptiometry scan (DPX-IQ Lunar, Lunar Corporation Madison, WI, USA) in the morning after an overnight fast. Transverse scans from head to toe measured absorption of $x$-ray beams at two different energy levels allowing for a valid determination of lean body mass, fat mass and fat percentage (Lukaski, 1993).

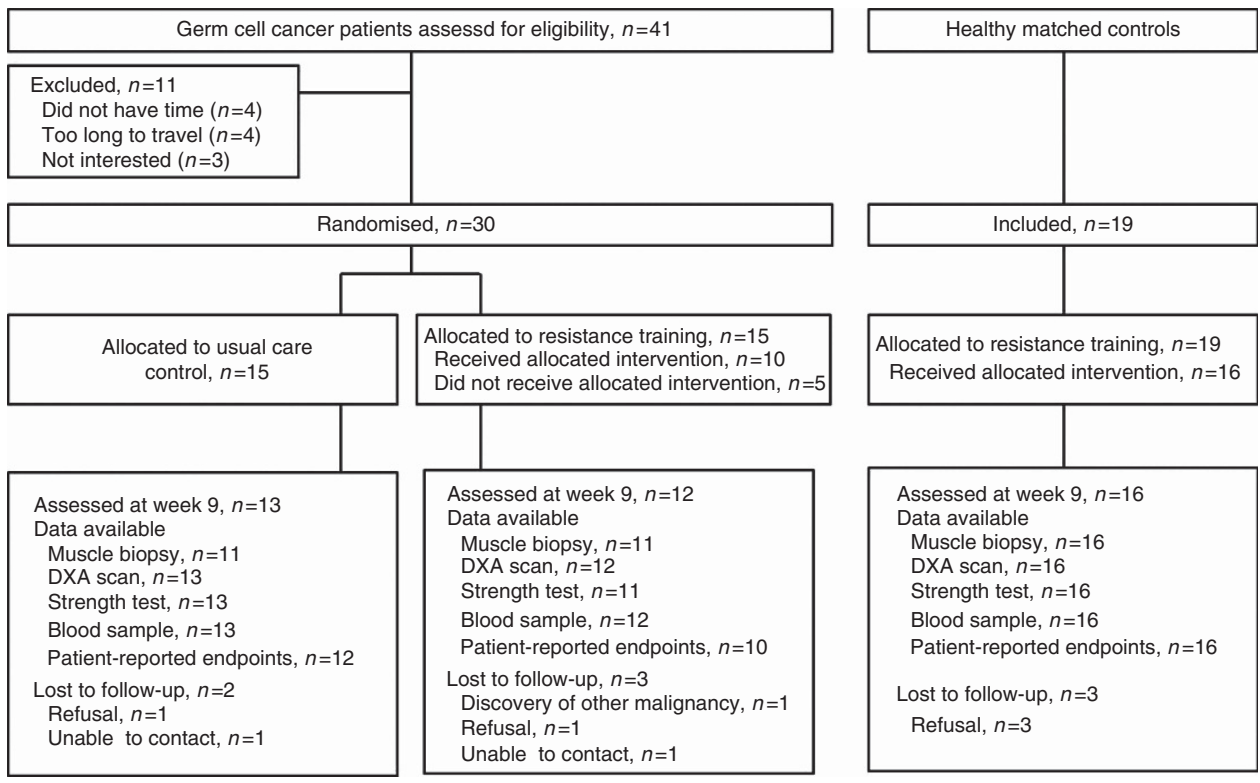

Figure 1. Trial design. Available data ( $n$ ) for each assessment method at week 9 is presented by study group.

Table 1. Baseline characteristics of study participants

\begin{tabular}{|c|c|c|c|}
\hline & $\begin{array}{l}\text { Usual care control group } \\
\text { (CON), } n=15\end{array}$ & $\begin{array}{l}\text { Resistance training group } \\
\text { (INT), } n=15\end{array}$ & $\begin{array}{l}\text { Healthy reference group } \\
\text { (REF), } n=19\end{array}$ \\
\hline Age, years (s.d.) & $35.8(8.9)$ & $34.4(7.6)$ & $31.5(6.0)$ \\
\hline Body mass index, $\mathrm{kg} \mathrm{m}^{-2}$ (s.d.) & $24.2(3.2)$ & $24.0(3.7)$ & $24.2(5.0)$ \\
\hline \multicolumn{4}{|l|}{ Smoking } \\
\hline $\begin{array}{l}\text { Current smoker, no. (\%) } \\
\text { Former smoker, no. (\%) }\end{array}$ & $\begin{array}{l}2(13 \%) \\
5(33 \%)\end{array}$ & $\begin{array}{l}0(0 \%) \\
5(33 \%)\end{array}$ & $\begin{array}{l}3(16 \%) \\
9(47 \%)\end{array}$ \\
\hline \multicolumn{4}{|l|}{ Physical activity level } \\
\hline Sedentary ${ }^{a}$, no. (\%) & $8(53 \%)$ & $7(47 \%)$ & $11(58 \%)$ \\
\hline \multicolumn{4}{|l|}{ Diagnosis } \\
\hline $\begin{array}{l}\text { Seminoma, no. (\%) } \\
\text { Non-seminoma, no. (\%) }\end{array}$ & $\begin{array}{l}7(47 \%) \\
8(53 \%)\end{array}$ & $\begin{array}{l}7(47 \%) \\
8(53 \%)\end{array}$ & $\begin{array}{l}\text { NA } \\
\text { NA }\end{array}$ \\
\hline Elevated tumour-markers, no. (\%) & $8(53 \%)$ & $7(47 \%)$ & NA \\
\hline $\begin{array}{l}\text { Elevated AFP, no. (\%) } \\
\text { Elevated HCG, no. (\%) }\end{array}$ & $\begin{array}{l}4(27 \%) \\
8(53 \%)\end{array}$ & $\begin{array}{l}3(20 \%) \\
6(40 \%)\end{array}$ & $\begin{array}{l}\text { NA } \\
\text { NA }\end{array}$ \\
\hline \multicolumn{4}{|l|}{ Orchiectomy } \\
\hline $\begin{array}{l}\text { Days from surgery, median (interquartile range) } \\
\text { Bilateral }^{\mathbf{b}} \text {, no. (\%) } \\
\text { Unilateral, no. (\%) }\end{array}$ & $\begin{array}{c}130(35-336) \\
1(7 \%) \\
14(93 \%)\end{array}$ & $\begin{array}{c}185(78-1618) \\
2(13 \%) \\
13(87 \%)\end{array}$ & $\begin{array}{l}\text { NA } \\
\text { NA } \\
\text { NA }\end{array}$ \\
\hline \multicolumn{4}{|l|}{ Gonadal status, serum } \\
\hline $\begin{array}{l}\text { Testosterone, } \mathrm{nmolI}^{-1} \\
\mathrm{FSH}, \mathrm{IUI}^{-1} \\
\mathrm{LH}, \mathrm{IUI}^{-1}\end{array}$ & $\begin{array}{c}17.0(4.9) \\
9.0(12.6) \\
4.3(3.6)\end{array}$ & $\begin{array}{c}18.8(6.5) \\
6.4(7.3) \\
2.2(1.9)\end{array}$ & $\begin{array}{l}\text { NA } \\
\text { NA } \\
\text { NA }\end{array}$ \\
\hline \multicolumn{4}{|c|}{$\begin{array}{l}\text { Abbreviations: AFP = alfa-phetoprotein; FSH= follicle-stimulating hormone; } \mathrm{HCG}=\text { human chorionic gonadotropin beta-chains; } L \mathrm{LH}=\text { luteinizing hormone; } N A=\text { not available. Continuous } \\
\text { variables are reported as mean (s.d.) and categorical variables are reported as numbers }(\%) \text {. There were no significant differences between groups }(P>0.05) \text {. } \\
\text { a'Sedentary' is defined as 'performing less than } 150 \text { min of moderate intensity physical activity per week'. } \\
{ }^{b} \text { Standard management of patients with bilateral orchiectomy includes testosterone substitution, but none of the patients included in this study had testosterone levels outside of the norma } \\
\text { range at the point of inclusion. }\end{array}$} \\
\hline
\end{tabular}


Biochemical metabolic profile included plasma concentrations of total cholesterol, high-density lipoprotein (HDL) cholesterol, low-density lipoprotein (LDL) cholesterol, triglycerides, glucose and insulin analysed by standard laboratory methods in blood samples drawn after an overnight fast.

Patient-reported outcomes included self-reported health-related quality of life assessed by Medical Outcomes Study Short Form-36 (MOS SF-36) (Ware and Sherbourne, 1992).

Safety was assessed by monitoring the incidence of the following clinically adverse events: postponement of BEP therapy and nonscheduled hospital visits. During RT sessions, minor adverse reactions such as discomfort, pain or nausea were also recorded.

Statistical analysis. Eleven patients per group provided $80 \%$ power to detect a between-group difference in fibre size of $500 \mu \mathrm{m}^{2}$ (assuming a s.d. of $400 \mu \mathrm{m}^{2}$ ) from baseline to week 9 at the $5 \%$ significance level. Fifteen patients per group were recruited to allow for a $20 \%$ attrition rate. Baseline characteristics and incidence of adverse events were compared across groups using Mann-Withney $U$-test and Fisher's exact test. A random effect model including fixed effects of 'group', 'assessment time' and their interaction and a random effect of 'participant' was used to analyse within-group changes from baseline to week 9. Analysis of covariance was used for between-group comparison of 'baseline-to-week 9 changes' while adjusting for age and baseline-values. The primary analysis compared the INT and the CON group using the intention-to-treat principle including all available data, and missing observations handled according to missing-at-random assumption. A secondary analysis compared the INT and the REF groups that only included participants who had attended at least 14 RT-sessions $(>50 \%$ adherence rate). All tests were two-tailed and significance level set at 0.05 .

\section{RESULTS}

Recruitment of participants took place from January 2011 to February 2013. Forty-one eligible GCC patients were contacted, and $30(73 \%)$ were randomised. The study flow is presented in Figure 1. Participant characteristics were balanced at baseline (Table 1). Twenty-five (83\%) participants completed week 9 assessments (CON group, $n=13$; INT group, $n=12$ ). Overall, the INT group attended a mean of 18.9 RT sessions (70\%; range: $0-100 \%)$.

There were no differences in clinical adverse events. Twentynine non-severe adverse reactions were observed in the INT group during RT, and on 25 occasions ( $\sim 10 \%$ of all sessions) a participant discontinued the session because of discomfort.

\section{Primary comparison: changes for GCC Patients by randomised group}

Primary end point. Intention-to-treat analysis showed that the muscle fibre size decreased by $-322 \mu \mathrm{m}^{2}$ (95\% confidence interval $(\mathrm{CI}):-899$ to $255 ; P=0.473$ ) in the CON group and increased by $+206 \mu \mathrm{m}^{2}$ (95\% CI: -384 to 796 ; $P=0.257$ ) in the INT group (adjusted mean difference (AMD), $+625 \mu \mathrm{m}^{2}, 95 \% \mathrm{CI}:-253$ to $1503, P=0.149)$. Type I fibre size decreased by $-209 \mu \mathrm{m}^{2}$ in the CON group and by $-5 \mu \mathrm{m}^{2}$ in the INT group (AMD, $+449 \mu \mathrm{m}^{2}$, $P=0.386)$. Type II fibre size decreased by $-495 \mu \mathrm{m}^{2}$ in the CON group and increased by $+424 \mu \mathrm{m}^{2}$ in the INT group (AMD, $+823 \mu \mathrm{m}^{2}, P=0.092$ ) (Figure 2, Table 2).

Secondary end points. Whole-body lean mass decreased by $-2.56 \mathrm{~kg}(P<0.001)$ in the CON group and by $-1.34 \mathrm{~kg}$ $(P=0.041)$ in the INT group (AMD, $+1.49 \mathrm{~kg}, P=0.07)$. Isometric strength decreased by $-21 \mathrm{Nm}(P=0.008)$ in the CON group and by $-5 \mathrm{Nm}(P=0.527)$ in the INT group (Table 2 , figure 3$)$.
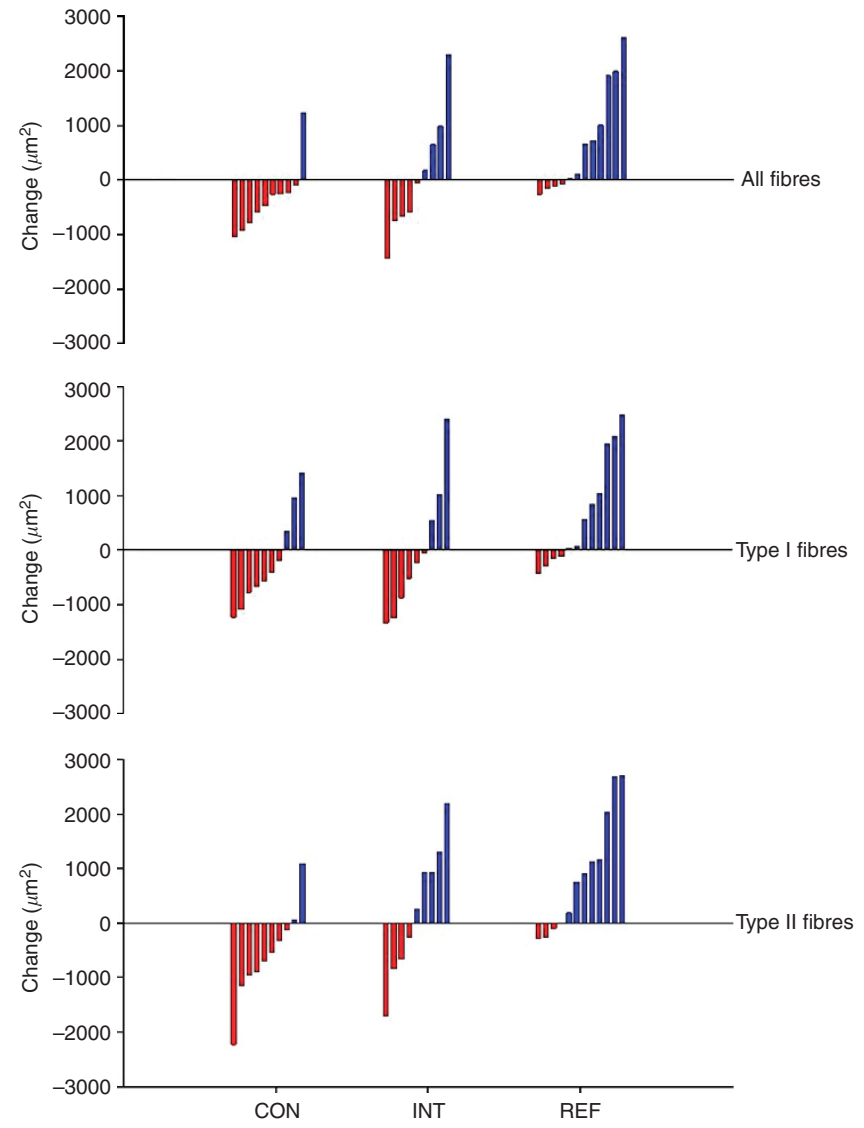

Figure 2. Individual changes in muscle fibre size (cross sectional area). Waterfall plot: red bars represent individual reduction in fibre size (atrophy), blue bars represent individual increase in fibre size (hypertrophy). Note: overall, seven muscle biopsy samples (from different individuals) were of poor quality and were not valid for fibre size analysis, thus only 10 (CON), 9 (INT) and 12 (REF) individuals with evaluable baseline and week-9 biopsies are presented in this figure.

Total plasma cholesterol increased by $+0.7 \mathrm{~mm}(P=0.013)$ in the CON group and by $+1.0 \mathrm{~mm}(P<0.001)$ in the INT group (AMD, $+0.6 \mathrm{~mm}, P=0.215)$. LDL cholesterol increased by $+0.6 \mathrm{~mm}(P=0.28)$ in the CON group and by $+1.0 \mathrm{~mm}$ $(P<0.001)$ in the INT group (AMD, $+0.5 \mathrm{mM}, P=0.175)$ and triglycerides increased by $+0.94 \mathrm{~mm}(P<0.001)$ in the INT group (Figure 4, Supplementary Table S1).

Patient reported that physical health decreased by -12.2 points $(P<0.001)$ in the CON group and by -11.4 points $(P<0.001)$ in the INT group (AMD; +1.11 points, $P=0.801$ ). The betweengroup difference for the 'role emotional' subscale in favour of the INT group approached significance (AMD, $+38, P=0.054$ ) (Supplementary Table S2).

Secondary comparison: efficacy of resistance training in GCC patients $v$ s healthy controls. Ten patients $(66 \%)$ in the INT group performed $\geqslant 14$ RT sessions with mean adherence of 22.6 sessions (84\%). This was similar to the REF group (mean 21.2 sessions (78\%)). In three of the four exercises, the REF group had higher average training load (Supplementary Table S3)

The REF group improved muscle fibre size (all fibres, $+768 \mu \mathrm{m}^{2}$; type I fibres, $+631 \mu \mathrm{m}^{2}$; type II fibres, $+1061 \mu \mathrm{m}^{2}$, all $\left.P<0.05\right)$, but the changes were not significantly different compared with changes observed in the INT group for all fibres (AMD, $-834 \mu \mathrm{m}^{2}$, $P=0.105)$, type I fibres (AMD, $\left.-802 \mu \mathrm{m}^{2}, P=0.12\right)$ or type II fibres (AMD, $-907 \mu \mathrm{m}^{2}, P=0.122$ ) (Table 2). 
Table 2. Effects on muscle end points

\begin{tabular}{|c|c|c|c|c|c|c|c|c|c|c|c|}
\hline & \multicolumn{2}{|c|}{ Baseline } & \multicolumn{2}{|c|}{ Week 9} & \multicolumn{3}{|c|}{ Within-group change } & \multicolumn{4}{|c|}{ Adjusted between-group difference } \\
\hline & Mean & s.d. & Mean & s.d. & Mean & $95 \% \mathrm{Cl}$ & $P$-value & Analysis & Mean & $95 \% \mathrm{Cl}$ & $P$-value \\
\hline \multicolumn{12}{|c|}{ CSA, all fibres, $\mu \mathrm{m}^{2}$} \\
\hline $\begin{array}{l}\text { CON } \\
\text { INT } \\
\text { REF }\end{array}$ & $\begin{array}{l}4576 \\
4877 \\
5057\end{array}$ & $\begin{array}{c}1028 \\
812 \\
1363\end{array}$ & $\begin{array}{l}4272 \\
5190 \\
5848\end{array}$ & $\begin{array}{c}605 \\
1108 \\
1670\end{array}$ & $\begin{array}{c}-322 \\
206 \\
768\end{array}$ & $\begin{array}{l}-899 \text { to } 255 \\
-384 \text { to } 796 \\
194 \text { to } 1341\end{array}$ & $\begin{array}{l}0.473 \\
0.257 \\
0.011\end{array}$ & $\begin{array}{l}\text { INT vs CON } \\
\text { INT vs REF }\end{array}$ & $\begin{array}{r}625 \\
-834\end{array}$ & $\begin{array}{l}-253 \text { to } 1503 \\
-1862 \text { to } 195\end{array}$ & $\begin{array}{l}0.149 \\
0.105\end{array}$ \\
\hline \multicolumn{12}{|c|}{ CSA, type I fibres, $\mu \mathrm{m}^{2}$} \\
\hline $\begin{array}{l}\text { CON } \\
\text { INT } \\
\text { REF }\end{array}$ & $\begin{array}{l}4439 \\
4931 \\
4799\end{array}$ & $\begin{array}{l}1226 \\
1010 \\
1339\end{array}$ & $\begin{array}{l}4241 \\
4943 \\
5355\end{array}$ & $\begin{array}{c}908 \\
1241 \\
1350\end{array}$ & $\begin{array}{c}-209 \\
-5 \\
631\end{array}$ & $\begin{array}{l}-877 \text { to } 460 \\
-690 \text { to } 681 \\
37 \text { to } 1225\end{array}$ & $\begin{array}{l}0.520 \\
0.988 \\
0.038\end{array}$ & $\begin{array}{l}\text { INT vs CON } \\
\text { INT vs REF }\end{array}$ & $\begin{array}{r}449 \\
-802\end{array}$ & $\begin{array}{l}-583 \text { to } 1481 \\
-1836 \text { to } 232\end{array}$ & $\begin{array}{l}0.368 \\
0.120\end{array}$ \\
\hline \multicolumn{12}{|c|}{ CSA, type II fibres, $\mu \mathrm{m}^{2}$} \\
\hline $\begin{array}{l}\text { CON } \\
\text { INT } \\
\text { REF }\end{array}$ & $\begin{array}{l}4854 \\
4925 \\
5174\end{array}$ & $\begin{array}{c}1241 \\
817 \\
1432\end{array}$ & $\begin{array}{l}4445 \\
5498 \\
6319\end{array}$ & $\begin{array}{c}488 \\
1361 \\
1740\end{array}$ & $\begin{array}{c}-495 \\
424 \\
1061\end{array}$ & $\begin{array}{l}-1161 \text { to } 172 \\
-258 \text { to } 1106 \\
413 \text { to }-1709\end{array}$ & $\begin{array}{l}0.137 \\
0.208 \\
0.003\end{array}$ & $\begin{array}{l}\text { INT vs CON } \\
\text { INT vs REF }\end{array}$ & $\begin{array}{r}823 \\
-907\end{array}$ & $\begin{array}{l}-151 \text { to } 1797 \\
-2083 \text { to } 270\end{array}$ & $\begin{array}{l}0.092 \\
0.122\end{array}$ \\
\hline \multicolumn{12}{|c|}{ Proportion type I, \% } \\
\hline $\begin{array}{l}\text { CON } \\
\text { INT } \\
\text { REF }\end{array}$ & $\begin{array}{l}44.2 \\
44.7 \\
40.8\end{array}$ & $\begin{array}{l}14.2 \\
17.2 \\
15.1\end{array}$ & $\begin{array}{l}42.7 \\
44.1 \\
49.7\end{array}$ & $\begin{array}{l}18.9 \\
13.7 \\
12.4\end{array}$ & $\begin{array}{r}-3.0 \\
-3.5 \\
10.3\end{array}$ & $\begin{array}{c}-10.2 \text { to } 4.2 \\
-10.6 \text { to } 3.7 \\
3.5 \text { to } 17.0\end{array}$ & $\begin{array}{l}0.389 \\
0.324 \\
0.004\end{array}$ & $\begin{array}{l}\text { INT vs CON } \\
\text { INT vs REF }\end{array}$ & $\begin{array}{r}0.0 \\
-10.7\end{array}$ & $\begin{array}{l}-10.8 \text { to } 10.9 \\
-21.0 \text { to }-0.4\end{array}$ & $\begin{array}{l}0.993 \\
0.042\end{array}$ \\
\hline \multicolumn{12}{|c|}{ Proportion type Ila, \% } \\
\hline $\begin{array}{l}\text { CON } \\
\text { INT } \\
\text { REF }\end{array}$ & $\begin{array}{l}40.0 \\
36.6 \\
42.6\end{array}$ & $\begin{array}{l}16.3 \\
12.9 \\
12.7\end{array}$ & $\begin{array}{l}35.3 \\
39.0 \\
43.4\end{array}$ & $\begin{array}{c}11.1 \\
14.2 \\
9.3\end{array}$ & $\begin{array}{r}-2.9 \\
4.5 \\
-0.7\end{array}$ & $\begin{array}{l}-9.2 \text { to } 3.4 \\
-1.8 \text { to } 10.7 \\
-6.6 \text { to } 5.3\end{array}$ & $\begin{array}{l}0.347 \\
0.155 \\
0.816\end{array}$ & $\begin{array}{l}\text { INT vs CON } \\
\text { INT vs REF }\end{array}$ & $\begin{array}{l}5.7 \\
3.1\end{array}$ & $\begin{array}{l}-2.7 \text { to } 14.0 \\
-6.3 \text { to } 12.5\end{array}$ & $\begin{array}{l}0.171 \\
0.495\end{array}$ \\
\hline \multicolumn{12}{|c|}{ Proportion type IIx, \% } \\
\hline $\begin{array}{l}\text { CON } \\
\text { INT } \\
\text { REF }\end{array}$ & $\begin{array}{l}15.8 \\
18.6 \\
16.6\end{array}$ & $\begin{array}{l}13.0 \\
10.0 \\
10.0\end{array}$ & $\begin{array}{c}22.0 \\
16.9 \\
6.9\end{array}$ & $\begin{array}{l}14.4 \\
9.3 \\
8.2\end{array}$ & $\begin{array}{r}6.0 \\
-1.2 \\
-9.5\end{array}$ & $\begin{array}{c}-1.0 \text { to } 13.0 \\
-8.1 \text { to } 5.7 \\
-14.4 \text { to }-4.6\end{array}$ & $\begin{array}{r}0.087 \\
0.727 \\
<0.001\end{array}$ & $\begin{array}{l}\text { INT vs CON } \\
\text { INT vs REF }\end{array}$ & $\begin{array}{r}-5.7 \\
7.2\end{array}$ & $\begin{array}{l}-16.0 \text { to } 4.4 \\
0.3 \text { to } 14.0\end{array}$ & $\begin{array}{l}0.244 \\
0.047\end{array}$ \\
\hline \multicolumn{12}{|c|}{ Cap. per fibre, no. } \\
\hline $\begin{array}{l}\text { CON } \\
\text { INT } \\
\text { REF }\end{array}$ & $\begin{array}{l}1.84 \\
2.02 \\
2.17\end{array}$ & $\begin{array}{l}0.52 \\
0.37 \\
0.53\end{array}$ & $\begin{array}{l}1.74 \\
1.92 \\
2.64\end{array}$ & $\begin{array}{l}0.28 \\
0.45 \\
0.84\end{array}$ & $\begin{array}{r}-0.09 \\
-0.20 \\
0.40\end{array}$ & $\begin{array}{l}-0.29 \text { to } 0.11 \\
-0.41 \text { to } 0.0 \\
0.17 \text { to } 0.63\end{array}$ & $\begin{array}{l}0.379 \\
0.055 \\
0.002\end{array}$ & $\begin{array}{l}\text { INT vs CON } \\
\text { INT vs REF }\end{array}$ & $\begin{array}{l}-0.03 \\
-0.60\end{array}$ & $\begin{array}{l}-0.36 \text { to } 0.29 \\
-1.00 \text { to }-0.20\end{array}$ & $\begin{array}{l}0.839 \\
0.005\end{array}$ \\
\hline \multicolumn{12}{|c|}{ Lean mass, kg } \\
\hline $\begin{array}{l}\text { CON } \\
\text { INT } \\
\text { REF }\end{array}$ & $\begin{array}{l}61.04 \\
60.84 \\
59.62\end{array}$ & $\begin{array}{l}5.39 \\
8.18 \\
8.22\end{array}$ & $\begin{array}{l}58.85 \\
60.06 \\
61.25\end{array}$ & $\begin{array}{l}4.19 \\
8.05 \\
9.04\end{array}$ & $\begin{array}{r}-2.56 \\
-1.34 \\
1.82\end{array}$ & $\begin{array}{l}-3.78 \text { to }-1.33 \\
-2.62 \text { to }-0.06 \\
0.98 \text { to } 2.66\end{array}$ & $\begin{array}{r}<0.001 \\
0.041 \\
<0.001\end{array}$ & $\begin{array}{l}\text { INT vs CON } \\
\text { INT vs REF }\end{array}$ & $\begin{array}{r}1.46 \\
-2.67\end{array}$ & $\begin{array}{c}-0.14 \text { to } 3.07 \\
-4.08 \text { to }-1.25\end{array}$ & $\begin{array}{r}0.073 \\
<0.001\end{array}$ \\
\hline \multicolumn{12}{|c|}{ Quadriceps strength, Nm } \\
\hline $\begin{array}{l}\text { CON } \\
\text { INT } \\
\text { REF }\end{array}$ & $\begin{array}{l}223 \\
247 \\
253\end{array}$ & $\begin{array}{l}36 \\
59 \\
62\end{array}$ & $\begin{array}{l}195 \\
249 \\
262\end{array}$ & $\begin{array}{l}39 \\
66 \\
67\end{array}$ & $\begin{array}{c}-21 \\
-5 \\
12\end{array}$ & $\begin{array}{c}-37 \text { to }-6 \\
-22 \text { to } 11 \\
4-20\end{array}$ & $\begin{array}{l}0.008 \\
0.527 \\
0.004\end{array}$ & $\begin{array}{l}\text { INT vs CON } \\
\text { INT vs REF }\end{array}$ & $\begin{array}{r}11 \\
-11\end{array}$ & $\begin{array}{l}-15 \text { to } 39 \\
-24 \text { to } 3\end{array}$ & $\begin{array}{l}0.399 \\
0.109\end{array}$ \\
\hline \multicolumn{12}{|c|}{1 - RM leg press, kg } \\
\hline $\begin{array}{l}\text { CON } \\
\text { INT } \\
\text { REF }\end{array}$ & $\begin{array}{l}\text { N.A } \\
155 \\
141\end{array}$ & $\begin{array}{l}38 \\
53\end{array}$ & $\begin{array}{l}\text { NA } \\
194 \\
184\end{array}$ & $\begin{array}{l}41 \\
48\end{array}$ & $\begin{array}{l}\text { NA } \\
43 \\
49\end{array}$ & $\begin{array}{l}31-55 \\
40-60\end{array}$ & $\begin{array}{l}<0.001 \\
<0.001\end{array}$ & $\begin{array}{l}\text { INT vs CON } \\
\text { INT vs REF }\end{array}$ & $\begin{array}{l}\text { NA } \\
-6\end{array}$ & -23 to 11 & 0.449 \\
\hline $\begin{array}{l}\text { Abbrev } \\
\text { referen } \\
\text { estimat } \\
\text { primary } \\
\text { RT grou } \\
\text { the sigr }\end{array}$ & $\begin{array}{l}\text { sted analy } \\
\text { cluded or } \\
\text { th level. }\end{array}$ & articipa & onfide & $\begin{array}{l}\| l \text { canc } \\
d \geqslant 14\end{array}$ & $\begin{array}{l}\text { roups bas } \\
\text { sessions; } t\end{array}$ & $\begin{array}{l}\text { on 'intention-to-treat } \\
\text { two germ cell cance }\end{array}$ & $\begin{array}{l}\text { sis' includi } \\
\text { ents (with } 0\end{array}$ & $\begin{array}{l}\text { area; INT = res } \\
\text { change may no } \\
\text { he end point ar }\end{array}$ & $\begin{array}{l}\text { ce trainin } \\
\text { cisely ref } \\
\text { e. Two s } \\
\text { vv REF: } \\
\text { from thi }\end{array}$ & $\begin{array}{l}\text { up; } \mathrm{Nm}=\text { newtonme } \\
\text { is difference given th } \\
\text { te analyses are prese } \\
\text { dary adjusted analysi } \\
\text { ysis. Bold entries are }\end{array}$ & $\begin{array}{l}\text { REF = healt } \\
\text { nean change } \\
\text { d: INT vs CO } \\
\text { tween the tv } \\
P \text {-values belc }\end{array}$ \\
\hline
\end{tabular}

The REF group improved muscle fibre phenotype composition, capillary density, lean mass, isometric strength and fat percentage (Figures 3 and 4, Table 2 and Supplementary Table S1). Significant between-group differences in favour of the REF group were seen for type I proportion (AMD $+10.7 \%, P=0.042$ ), type IIx proportion (AMD, $-7.2 \%, P=0.047$ ), capillary density (AMD + 0.6 cap. per 

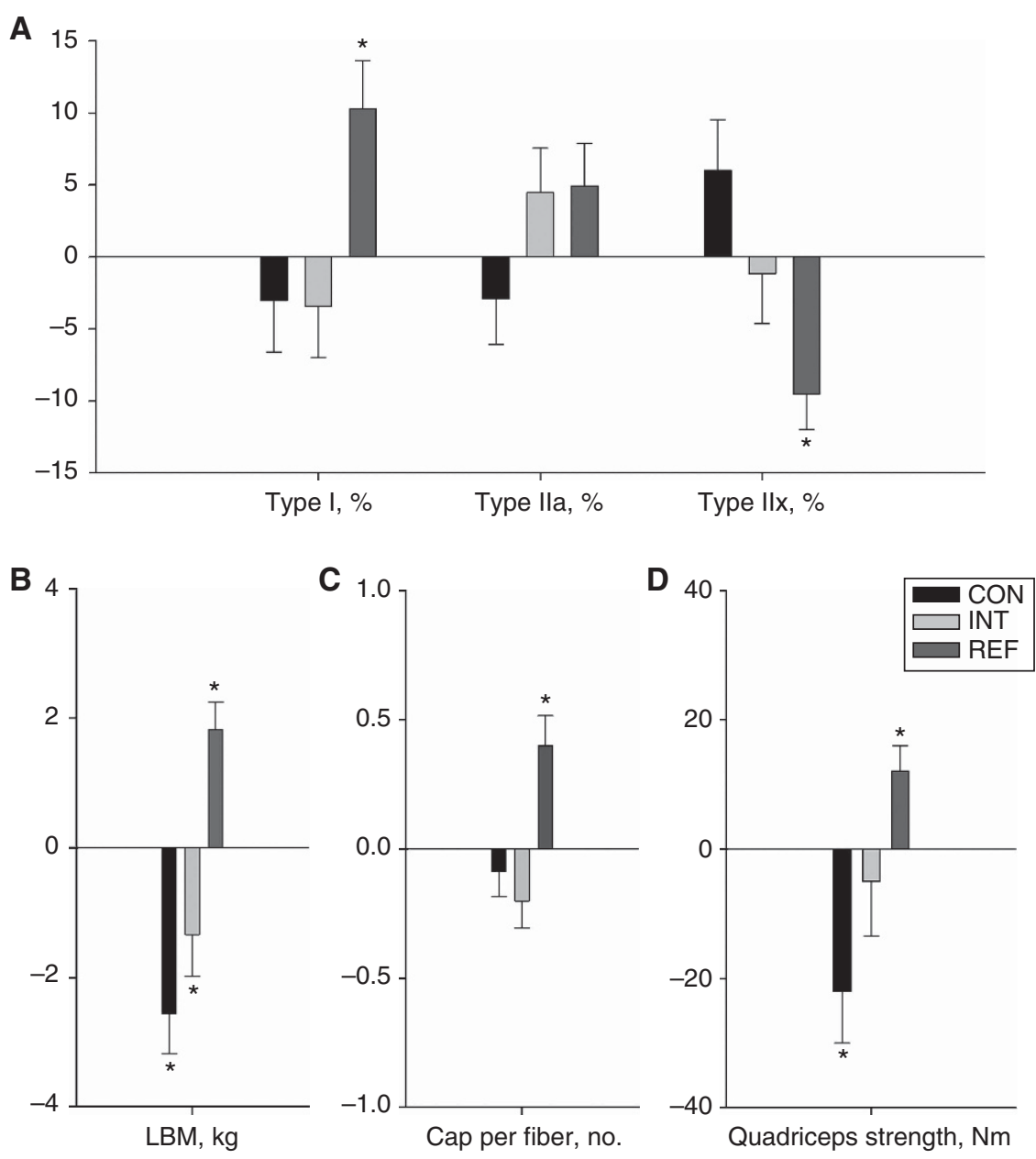

Figure 3. Within-group changes in secondary muscular end points. Random effect model-based within-group mean changes (s.e.m.) from baseline to week 9 based on all available data presented for (A) proportion of muscle fibre phenotypes: type I/type Ila/type Ilx; (B) whole-body lean mass, (C) capillaries per fibre; (D) isometric quadriceps strength. * denotes within-group change significantly different from zero, $P<0.05$. Abbreviations: cap $=$ capillaries; $L B M=$ lean body mass.

fibre, $P=0.005)$, lean mass (AMD, $+2.67 \mathrm{~kg}, P<0.001)$ compared with the INT group (Table 2). Also, significant between-group differences in favour of the REF group were found for fat percentage (AMD, $+3.1 \%, P=0.002)$, total cholesterol (AMD, $-1.3 \mathrm{mM}$, $P<0.001$ ), LDL cholesterol (AMD, $-1.1 \mathrm{~mm}, P<0.001$ ), triglycerides (AMD, $-1.00 \mathrm{~mm}, P=0.008)$ and insulin (AMD, $-16 \mathrm{pM}$, $P=0.008)$ (Supplementary Table S1).

\section{DISCUSSION}

Muscle dysfunction is considered a candidate mechanism associated with incidence and prognosis of metabolic syndrome and CV events in the general population (Sayer et al, 2007; Ruiz et al, 2008). Evidence showing GCC survivors treated with BEP have increased incidence of these conditions, provided a strong rationale to investigate the effects of BEP on muscular function and whether this could be mitigated by RT. Our principal finding was that BEP was associated with negative changes across various muscular end points, in parallel with unfavourable changes in lipid metabolic profile and quality of life. Moreover, RT was safe, feasible and attenuated BEP-induced dysfunction in selected end points, but BEP blunted several RT-induced adaptations in muscle function.

An important finding was that 9 of 10 evaluable patients in the CON group had reduced mean muscle fibre size after therapy, and also displayed trends toward qualitative changes in phenotype distribution with an average increase of $+6 \%$ in the proportion of glycolytic type IIx fibres. Increased proportion of this glycolytic phenotype has been found to be highly expressed in subjects with poor insulin sensitivity (Nyholm et al, 1997). Although not statistically significant, this data to our knowledge is the first to indicate that systemic anti-cancer treatment may be associated with unfavourable changes in muscle fibre morphology on a cellular level. Also, the reduction in lean mass $(\sim 2.5 \mathrm{~kg})$ in the CON group was larger than what has been observed during 6 months of sorafenib therapy for advanced stage renal cell carcinoma (Antoun et al, 2010). It is arguably not possible to identify a single, major deteriorating factor in a clinical setting, which uses a combination of three anti-neoplastic agents. Cisplatin may, however, comprise a primary culprit, as studies have shown this stimulates induction of muscle atrophy-related genes, proteosomal proteolysis, and inflammation through the NF- $\kappa \mathrm{B}$ signalling pathway in vitro (Fanzani et al, 2011). Moreover, cisplatin is neurotoxic possibly inhibiting motorunit neural drive (Rabik and Dolan, 2007), which in turn may cause atrophy and changes toward glycolytic phenotypes.

Given the detrimental impact of BEP on muscle function, an important finding of the present study was that supervised progressive RT was safe and feasible during BEP. Overall, mean adherence rate to RT was concordant with previously supervised exercise trials during chemotherapy (Courneya et al, 2007; 

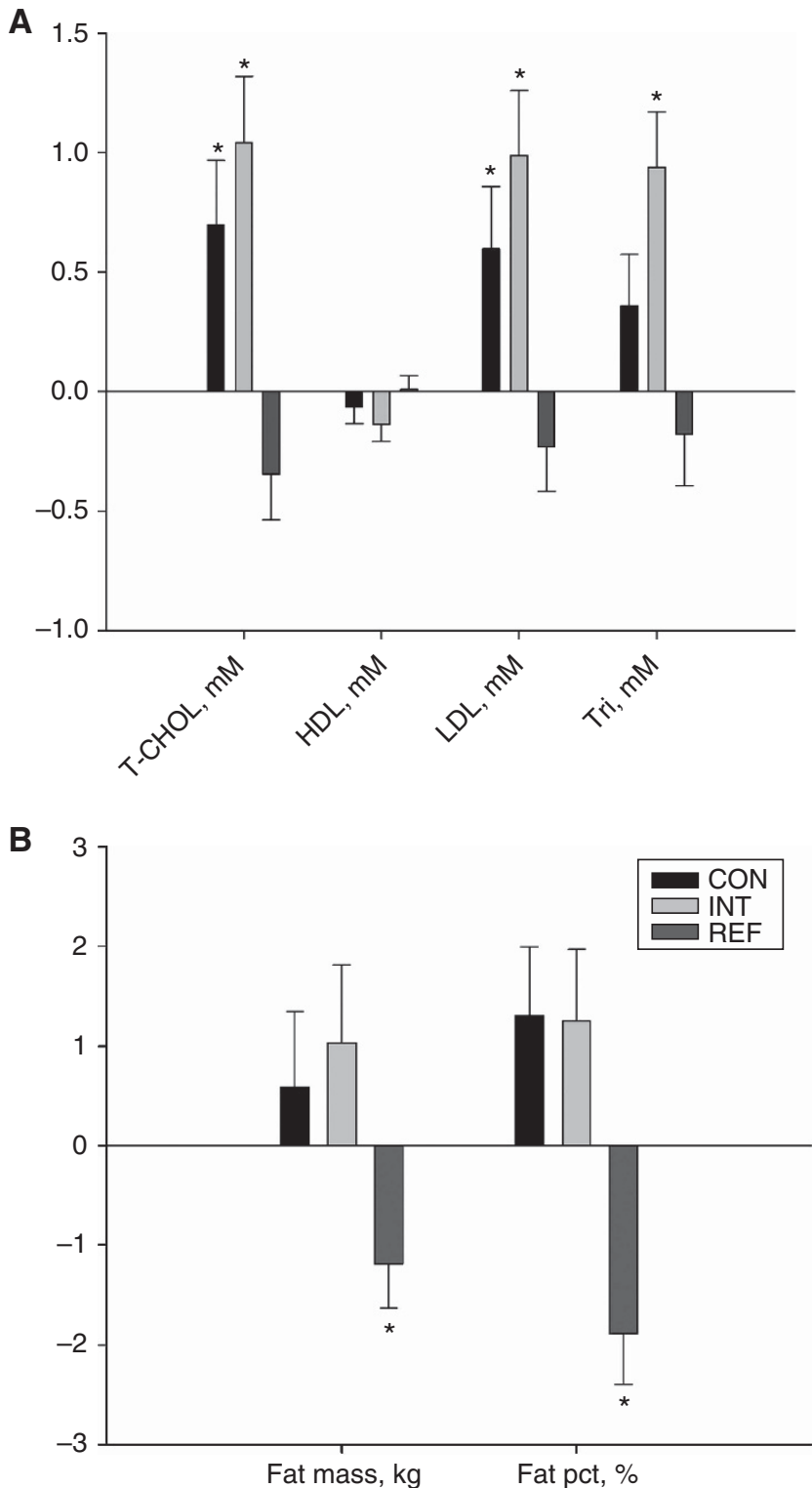

Figure 4. Within-group changes in selected metabolic end points. Random effect model-based within-group mean changes (s.e.m.) from baseline to week 9 based on all available data presented for (A) plasma lipid concentrations: Total cholesterol/HDL cholesterol/LDL

cholesterol/triglycerides; (B) fat mass/fat percentage. * denotes withingroup change significantly different from zero, $P<0.05$. Abbreviations: $\mathrm{HDL}=$ high-density lipoprotein; $\mathrm{LDL}=$ low-density lipoprotein;

pct $=$ percentage $; \mathrm{T}-\mathrm{CHOL}=$ total cholesterol; $\mathrm{Tr}=$ triglycerides .

Adamsen et al, 2009) and RT did not increase (nor reduce) the number of clinical adverse events. GCC patients are treated with relatively high chemotherapeutic doses that may cause myelosuppression and increased risk of neutropenia/infections (Feldman et al, 2008). Therapy complications did render two patients unable to perform RT, and $\sim 10 \%$ of all RT sessions were discontinued due to minor adverse reactions, that is, nausea, dizziness or pain. Thus, demonstration of the overall feasibility and safety of progressive RT in the present context is novel and important, but this also emphasises that individual monitoring and collaboration with oncologists is imperative to minimise the risk of compromising therapy administration and/or augmenting BEPrelated side effects.

For intention-to-treat analyses, we found no significant differences between the INT and CON group, although trends across several end points indicated that RT in the present setting attenuated the level of muscle dysfunction. The between-group differences for changes in muscle fibre size actually exceeded our a priori target $\left(+500 \mu \mathrm{m}^{2}\right)$ but remained non-significant due, at least in part, to larger-than-expected within-group variation. No studies are available for direct comparison as muscle fibre assessments have not been previously performed in the exercise oncology setting, but the difference in lean mass change $(\sim 1.5 \mathrm{~kg})$, was comparable with or larger than that of previous RT trials during anticancer therapy (Galvao et al, 2010; Strasser et al, 2013). Moreover, the INT group maintained their pretreatment in isometric quadriceps strength, whereas the CON group significantly decreased in muscle strength, and the INT group also significantly improved muscle strength $(+28 \%)$ evaluated by 1 RM test. This suggests, that 9 weeks ( $\sim 19$ sessions) of progressive RT in GCC patients during BEP had a comparable effect on muscle strength as RT interventions with higher volume (12-52 weeks duration) in other malignancies (Strasser et al, 2013).

In both GCC groups, we found trends toward increased adiposity and significant increases in plasma lipid concentrations, which are known to be strongly associated with the risk of developing metabolic disorders and $\mathrm{CV}$ events (Pletcher et al, 2010). Sharrett et al (2001) showed that an increase of $\sim 1 \mathrm{~mm}$ in total cholesterol (similar to what we found in the present study) was associated with age- and race-adjusted relative risk of 1.34 in men for developing coronary heart disease. It should be noted, however, that a recent study in GCC patients showed that lipid concentrations 9 months post therapy were similar to pretreatment levels (Willemse et al, 2013), which questions whether this acute rise in lipid concentrations is involved in the onset of late disorders.

We found similar changes in patient-reported quality of life in both GCC groups with reductions in the physical component scale $(\sim 12$ points $)$ and several subscales of the SF-36questionnaire. The trend toward improvement of the 'emotional role' subscale in favour of the INT group should be interpreted with care, but is in accordance with a large body of evidence showing participation in exercise programs can improve psychosocial end points in the oncology setting (Schmitz et al, 2005; Schmitz et al, 2010).

The clinical implications of our findings remain to be determined. It is noteworthy, however, that incidence rates of chronic disorders are strongly associated with age-related decline in muscle function (sarcopenia), which onsets in the 6th life decade and accounts for an estimated loss of $1.9 \mathrm{~kg}$ lean mass per decade (Janssen et al, 2000). From a muscle physiological perspective, the reduction in lean mass observed in GCC patients during 9 weeks of BEP therapy appears to be equivalent to more than a decade of physiological aging. Interestingly, this relative decline is comparable with the reduction in cardio pulmonary exercise capacity shown in women undergoing chemotherapy for earlystage breast cancer (Hornsby et al, 2013). Although a proportion of patients may recover this deficit spontaneously after completion of therapy, some individuals potentially struggle to return to their preillness level (Koelwyn et al, 2012), emphasising the need for countermeasures protecting against therapy-related physiological deterioration.

Within the field of exercise oncology, the safety and efficacy of structured exercise have been investigated across various diagnoses and settings (Schmitz et al, 2010). Despite the rapidly growing body of evidence supporting the application of exercise in the oncology setting, it remains relatively poorly explored to what extend cancer and its treatments influence the adaptation response to exercise training. Thus, an important finding of the present study was that patients undergoing cytotoxic therapies, for several outcomes were not equally responsive to RT as their age-matched 
healthy counterparts. As expected, we found RT-induced improvements in the healthy REF group across all measures of muscle function. Compared with these wide-ranging positive effects, we found the changes in the INT group were either considerably blunted or in some cases abolished, which suggests that BEP may alter muscle malleability to contractile activity. The difference in response may, at least in part, be attributed to the fact that the REF group had significantly higher average training load. Also, the concomitant administration of corticoid-steroids, which is known to cause various unfavourable muscular effects, may inhibite anabolic pathways involved in hypertrophy (Short et al, 2009). In concert, our findings suggests that while RT-induced improvements in muscle function may be achievable in some GCC patients, the effects cannot be predicted during BEP, which limits the general applicability of resistance training in this clinical context.

The present study has important limitations, first and foremost the relatively small sample size and a considerable number of statistical tests increasing the risk of type I and type II errors. Second, we did not control for use of antiemetic treatment. Patients are prescribed the same absolute dose of prednisolone, which may have influenced the physiological impact on skeletal muscle, since doses relative to body weight/body surface area differed. Finally, there was likely a case of selection bias, as the present study appealed to participants motivated for exercise, and also there was risk of bias associated with certain assessments, as personnel responsible for secondary end points were not blinded to group assignment.

In summary, BEP was associated with significant reductions in lean mass and strength and trends toward atrophy and an unfavourable phenotype composition in patients with GCC, in parallel with negative changes in metabolic profile. Hospital-based, supervised RT was safe and attenuated the reduction in fibre size, lean mass and strength, but BEP blunted several positive RT adaptations found in healthy subjects. Since GCC patients undergoing BEP were not equally responsive to RT as healthy individuals, and RT did not protect against changes in metabolic homoeostasis, our study does not support the general application of resistance training in this setting, but larger-scaled trials are required to confirm our findings. Also, prospective follow-up studies are needed to explore whether the considerable level of therapy-induced muscle dysfunction found immediately after the completion of treatment plays a role in the onset of long-term disorders among GCC survivors.

\section{ACKNOWLEDGEMENTS}

This study was supported by Copenhagen University Hospital (Rigshospitalet), the Beckett Foundation and the Centre for Integrated Rehabilitation of Cancer Patients (CIRE); a centre established and supported by The Danish Cancer Society and The Novo Nordic Foundation. Current controlled trials ISRCTN32132990.

\section{CONFLICT OF INTEREST}

The authors declare no conflict of interest.

\section{REFERENCES}

Adamsen L, Quist M, Andersen C, Moller T, Herrstedt J, Kronborg D, Baadsgaard MT, Vistisen K, Midtgaard J, Christiansen B, Stage M, Kronborg MT, Rorth M (2009) Effect of a multimodal high intensity exercise intervention in cancer patients undergoing chemotherapy: randomised controlled trial. BMJ 339: b3410.
Andersen JL, Aagaard P (2000) Myosin heavy chain IIX overshoot in human skeletal muscle. Muscle Nerve 23(7): 1095-1104.

Antoun S, Birdsell L, Sawyer MB, Venner P, Escudier B, Baracos VE (2010) Association of skeletal muscle wasting with treatment with sorafenib in patients with advanced renal cell carcinoma: results from a placebocontrolled study. J Clin Oncol 28(6): 1054-1060.

Atlantis E, Martin SA, Haren MT, Taylor AW, Wittert GA (2009) Inverse associations between muscle mass, strength, and the metabolic syndrome. Metabolism 58(7): 1013-1022.

Bergström J (1962) Muscle electrolytes in man. Scand J Clin Lab Invest 68: 1-110. Beyer J, Albers P, Altena R, Aparicio J, Bokemeyer C, Busch J, Cathomas R, Cavallin-Stahl E, Clarke NW, Classen J, Cohn-Cedermark G, Dahl AA, Daugaard G, De GU, De SM, De WM, De WR, Dieckmann KP, Fenner M, Fizazi K, Flechon A, Fossa SD, Germa Jr L, Gietema JA, Gillessen S, Giwercman A, Hartmann JT, Heidenreich A, Hentrich M, Honecker F, Horwich A, Huddart RA, Kliesch S, Kollmannsberger C, Krege S, Laguna MP, Looijenga LH, Lorch A, Lotz JP, Mayer F, Necchi A, Nicolai N, Nuver J, Oechsle K, Oldenburg J, Oosterhuis JW, Powles T, Rajpert-De ME, Rick O, Rosti G, Salvioni R, Schrader M, Schweyer S, Sedlmayer F, Sohaib A, Souchon R, Tandstad T, Winter C, Wittekind C (2013) Maintaining success, reducing treatment burden, focusing on survivorship: highlights from the third European consensus conference on diagnosis and treatment of germ-cell cancer. Ann Oncol 24(4): 878-888.

Christensen JF, Andersen JL, Adamsen L, Lindegaard B, Mackey AL, Nielsen RH, Rorth M, Daugaard G (2011) Progressive resistance training and cancer testis (PROTRACT) - efficacy of resistance training on muscle function, morphology and inflammatory profile in testicular cancer patients undergoing chemotherapy: design of a randomized controlled trial. BMC Cancer 11: 326. Christensen JF, Jones LW, Andersen JL, Daugaard G, Rorth M, Hojman P (2014) Muscle dysfunction in cancer patients. Ann Oncol 25(5): 947-958. Courneya KS, Segal RJ, Mackey JR, Gelmon K, Reid RD, Friedenreich CM, Ladha AB, Proulx C, Vallance JK, Lane K, Yasui Y, McKenzie DC (2007) Effects of aerobic and resistance exercise in breast cancer patients receiving adjuvant chemotherapy: a multicenter randomized controlled trial. J Clin Oncol 25(28): 4396-4404.

Egan B, Zierath JR (2013) Exercise metabolism and the molecular regulation of skeletal muscle adaptation. Cell Metab 17(2): 162-184.

Einhorn LH (1990) Treatment of testicular cancer: a new and improved model. J Clin Oncol 8(11): 1777-1781.

Eves ND, Plotnikoff RC (2006) Resistance training and type 2 diabetes: considerations for implementation at the population level. Diabetes Care 29(8): 1933-1941.

Fanzani A, Zanola A, Rovetta F, Rossi S, Aleo MF (2011) Cisplatin triggers atrophy of skeletal C2C12 myotubes via impairment of Akt signalling pathway and subsequent increment activity of proteasome and autophagy systems. Toxicol Appl Pharmacol 250(3): 312-321.

Feldman DR, Bosl GJ, Sheinfeld J, Motzer RJ (2008) Medical treatment of advanced testicular cancer. JAMA 299(6): 672-684.

Fossa SD, Gilbert E, Dores GM, Chen J, McGlynn KA, Schonfeld S, Storm H, Hall P, Holowaty E, Andersen A, Joensuu H, Andersson M, Kaijser M, Gospodarowicz M, Cohen R, Pukkala E, Travis LB (2007) Noncancer causes of death in survivors of testicular cancer. J Natl Cancer Inst 99(7): 533-544.

Galvao DA, Taaffe DR, Spry N, Joseph D, Newton RU (2010) Combined resistance and aerobic exercise program reverses muscle loss in men undergoing androgen suppression therapy for prostate cancer without bone metastases: a randomized controlled trial. J Clin Oncol 28(2): 340-347.

Haugnes HS, Wethal T, Aass N, Dahl O, Klepp O, Langberg CW, Wilsgaard T, Bremnes RM, Fossa SD (2010) Cardiovascular risk factors and morbidity in long-term survivors of testicular cancer: a 20 -year follow-up study. J Clin Oncol 28(30): 4649-4657.

Hornsby WE, Douglas PS, West MJ, Kenjale AA, Lane AR, Schwitzer ER, Ray KA, Herndon JE, Coan A, Gutierrez A, Hornsby KP, Hamilton E, Wilke LG, Kimmick GG, Peppercorn JM, Jones LW (2013) Safety and efficacy of aerobic training in operable breast cancer patients receiving neoadjuvant chemotherapy: a phase II randomized trial. Acta Oncol 53: 65-74.

International Germ Cell Cancer Collaborative Group (1997) International germ cell consensus classification: a prognostic factor-based staging system for metastatic germ cell cancers. International Germ Cell Cancer Collaborative Group. J Clin Oncol 15(2): 594-603.

Janssen I, Heymsfield SB, Wang ZM, Ross R (2000) Skeletal muscle mass and distribution in 468 men and women aged 18-88yr. J Appl Physiol 89(1): 81-88. 
Koelwyn GJ, Khouri M, Mackey JR, Douglas PS, Jones LW (2012) Running on empty: cardiovascular reserve capacity and late effects of therapy in cancer survivorship. J Clin Oncol 30(36): 4458-4461.

Lukaski HC (1993) Soft tissue composition and bone mineral status: evaluation by dual-energy X-ray absorptiometry. J Nutr 123(2 Suppl): 438-443.

Nyholm B, Qu Z, Kaal A, Pedersen SB, Gravholt CH, Andersen JL, Saltin B, Schmitz O (1997) Evidence of an increased number of type IIb muscle fibers in insulin-resistant first-degree relatives of patients with NIDDM. Diabetes 46(11): 1822-1828.

Pletcher MJ, Bibbins-Domingo K, Liu K, Sidney S, Lin F, Vittinghoff E, Hulley SB (2010) Nonoptimal lipids commonly present in young adults and coronary calcium later in life: the CARDIA (Coronary Artery Risk Development in Young Adults) study. Ann Intern Med 153(3): 137-146.

Puhan MA, Schunemann HJ, Frey M, Scharplatz M, Bachmann LM (2005) How should COPD patients exercise during respiratory rehabilitation? comparison of exercise modalities and intensities to treat skeletal muscle dysfunction. Thorax 60(5): 367-375.

Rabik CA, Dolan ME (2007) Molecular mechanisms of resistance and toxicity associated with platinating agents. Cancer Treat Rev 33(1): 9-23.

Ruiz JR, Sui X, Lobelo F, Morrow Jr JR, Jackson AW, Sjostrom M, Blair SN (2008) Association between muscular strength and mortality in men: prospective cohort study. BMJ 337: a439.

Sayer AA, Dennison EM, Syddall HE, Gilbody HJ, Phillips DI, Cooper C (2005) Type 2 diabetes, muscle strength, and impaired physical function: the tip of the iceberg? Diabetes Care 28(10): 2541-2542.

Sayer AA, Syddall HE, Dennison EM, Martin HJ, Phillips DI, Cooper C, Byrne CD (2007) Grip strength and the metabolic syndrome: findings from the Hertfordshire Cohort Study. QJM 100(11): 707-713.

Schmitz KH, Courneya KS, Matthews C, mark-Wahnefried W, Galvao DA, Pinto BM, Irwin ML, Wolin KY, Segal RJ, Lucia A, Schneider CM, von G,V, Schwartz AL (2010) American College of Sports Medicine roundtable on exercise guidelines for cancer survivors. Med Sci Sports Exerc 42(7): $1409-1426$.

Schmitz KH, Holtzman J, Courneya KS, Masse LC, Duval S, Kane R (2005) Controlled physical activity trials in cancer survivors: a systematic review and meta-analysis. Cancer Epidemiol Biomarkers Prev 14(7): $1588-1595$.

Sharrett AR, Ballantyne CM, Coady SA, Heiss G, Sorlie PD, Catellier D, Patsch W (2001) Coronary heart disease prediction from lipoprotein cholesterol levels, triglycerides, lipoprotein(a), apolipoproteins A-I and B, and HDL density subfractions: The Atherosclerosis Risk in Communities (ARIC) Study. Circulation 104(10): 1108-1113.

Short KR, Bigelow ML, Nair KS (2009) Short-term prednisone use antagonizes insulin's anabolic effect on muscle protein and glucose metabolism in young healthy people. Am J Physiol Endocrinol Metab 297(6): E1260-E1268.

Strasser B, Steindorf K, Wiskemann J, Ulrich CM (2013) Impact of resistance training in cancer survivors: a meta-analysis. Med Sci Sports Exerc 45(11): 2080-2090.

Ware Jr JE, Sherbourne CD (1992) The MOS 36-item short-form health survey (SF-36). I. Conceptual framework and item selection. Med Care 30(6): 473-483.

Willemse PP, van der Meer RW, Burggraaf J, van Elderen SG, de Kam ML, de RA, Lamb HJ, Osanto S (2013) Abdominal visceral and subcutaneous fat increase, insulin resistance and hyperlipidemia in testicular cancer patients treated with cisplatin-based chemotherapy. Acta Oncol 53(3): $351-360$.

This work is published under the standard license to publish agreement. After 12 months the work will become freely available and the license terms will switch to a Creative Commons AttributionNonCommercial-Share Alike 3.0 Unported License.

Supplementary Information accompanies this paper on British Journal of Cancer website (http://www.nature.com/bjc) 